\title{
Teacher's Job Satisfaction and Its Relationship with Their Work Performance, Professionalism, and Commitment
}

\author{
Angelica 0. Cortez, Sheena Mai A. Galman, Jennifer Amaranto, \\ Mary Jane L. Tomas, Marlon V. Rufino \\ College of Education, Nueva Ecija University of Science and Technology, Cabanatuan City, Philippines \\ Email: sheenamaiagalman@gmail.com
}

How to cite this paper: Cortez, A.O., Galman, S.M.A., Amaranto, J., Tomas, M.J.L. and Rufino, M.V. (2021) Teacher's Job Satisfaction and Its Relationship with Their Work Performance, Professionalism, and Commitment. Open Access Library Journal, 8: e7397.

https://doi.org/10.4236/oalib.1107397

Received: April 8, 2021

Accepted: May 9, 2021

Published: May 12, 2021

Copyright $\odot 2021$ by author(s) and Open Access Library Inc.

This work is licensed under the Creative Commons Attribution International License (CC BY 4.0).

http://creativecommons.org/licenses/by/4.0/

\begin{abstract}
The study described the work performance, degree of professionalism and work commitment of teacher education faculty members of Nueva Ecija University of Science and Technology as indicators of work satisfaction. Teacher's performance was based from the ratings of IPCR, while professionalism in work was expressed utilizing the reports of the Human Resource Management on Tardiness and Under time. Commitment as an indicator was based from the length of service incurred by the faculty including the service awards received while in service. Descriptive normative survey was employed engaging 42 full time faculty members of the College. Gathered data were analyzed using frequency count and weighted mean while degree of relationship was determined by employing correlation analysis. Results showed that respondents were generally very satisfied with their work and that this satisfaction level was found not significantly related with work performance, degree of professionalism and commitment of the teachers towards work.
\end{abstract}

\section{Subject Areas}

Human Resource Management

\section{Keywords}

Job Satisfaction, Professionalism, Relationship, Work Performance, Work

Commitment

\section{Introduction}

Normally and generally, an employee works five-days per week. If an employee 
works in any government agency, the required 40 -hour work is distributed in 5 working days. For private entities, some practice flexibility while other conforms similarly with the work arrangement of government agencies, especially, if the entity is an educational institution with teachers as among the employees.

Having a job is one very important matter for economic reason among other things, but then, discharging duties entail lots of responsibilities alongside social standing and status. But then, while staying in whatever job one may have, other equally important matters arise and some of these are the matters on job satisfaction, work performance, commitment, and professionalism.

How these variables are related with each other?

According to Smith (2008) [1], one's behavior affects engagement and satisfaction which means that satisfaction leads to performance and performance leads to satisfaction. Satisfied employees tend to be more productive, creative and exhibit high level of professionalism said Syptak, Marsland and Ulmer (1999) [2]. These findings are fully supported by the findings of Judge \& Church in 2003 [3] when their study arrived at a conclusion that job satisfaction includes multidimensional psychological responses to an individual's job, and that these are in the forms of cognitive aspects (evaluative), affective (emotional) and behavioral components. Moreover, as expounded by the conclusions of Bernstein and Nash (2008) [4], the emotional component refers to feelings regarding the job such as boredom, anxiety, or excitement; the cognitive component of job satisfaction is described as the feeling that one's job is mentally demanding or challenging; and behavioral component includes people's action regarding their work, which may include being tardy, staying late or pretending to be ill in order to avoid.

The study on the relationship of job satisfaction with job performance, job commitment and professionalism of teachers, is one of the most admired (Judge, T.A. et al., 2001) [5] and well researched area, in which outputs served as basis for organizational actions, and it is but necessary, that this research be conducted on a regular basis, hence, the conduct of this study.

\section{Conceptual Framework}

In the study of Judge, T.A. et al. in 2001 [5], there were at least seven suggested models in which satisfaction-performance relationship was established. One of these models was modified resulting to Figure 1.

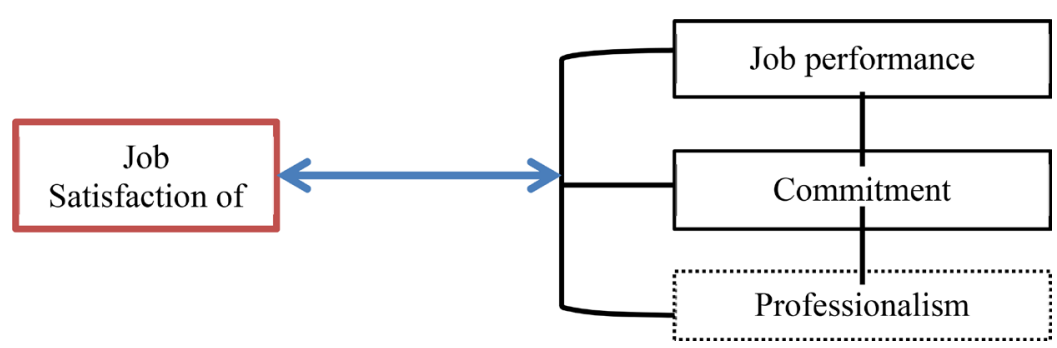

Figure 1. Research paradigm. 
Research and discussions investigating job satisfaction-performance relationship have been conducted in many times and correlation between the constructs have been established but differ from one to another, and from one profession to another. As shown in Figure 1, this study will determine the relation of job satisfaction with teacher's job performance, commitment and professionalism.

\section{Methods}

\subsection{Research Method}

The study made used of descriptive-correlational research design as it described the level of job satisfaction of the teachers and relate the same with teacher's job performance, commitment and professionalism.

\subsection{Sample and Sampling Technique}

A total of forty-two full-time faculty members of the College of Education, all in permanent status, were engaged in the study, thus employing purposive sampling. The number constitutes the total number of all the faculty members of the college.

Table 1 shows the profile of the respondents as to age, gender and academic rank.

As an old and proven fact, the teaching profession is still dominated by female teachers since $62 \%$ of the teaching force of the College of Education is female and only $38 \%$ is male. Also, data showed that more than half of the teaching force (about 52\%) belonged to the forty years old and above group which means that there were more senior faculty members that new ones. Moreover, the said group have academic ranks varying from professor, associate and assistant professor and about $45 \%$ are instructors.

\subsection{Data Gathering Techniques and Research Instruments}

Data for this study were collected based on the responses of the respondents to a

Table 1. Profile of the respondents in terms of age, gender, and academic rank.

\begin{tabular}{cccc}
\hline \multicolumn{2}{c}{ Variables } & Frequency & Percentage \\
\hline & Below 30 years old & 2 & $5 \%$ \\
Age & $30-40$ & 18 & $43 \%$ \\
& $41-50$ & 10 & $23 \%$ \\
Above 50 years old & Female & 12 & $29 \%$ \\
Gender & Male & 26 & $62 \%$ \\
& Professor & 16 & $38 \%$ \\
\hline Academic Rank & Associate Professor & 3 & $7 \%$ \\
& Assistant Professor & 11 & $27 \%$ \\
& Instructor & 9 & $21 \%$
\end{tabular}


questionnaire intended for establishing the job satisfaction of the teachers. The research questionnaire was patterned to the provisions of the University Manual as to fringe benefits. It has two parts. Part one solicited data on selected profile variables such as age, gender, length of service in the institution, and academic rank. Part two gathered data on the respondents' extrinsic and intrinsic job satisfaction in which level of satisfaction was expressed utilizing a 1 - 5 Likert scale where 5 means highly satisfied, 4 means very satisfied, 3 means satisfied, 2 means slightly satisfied, and 1 means not satisfied. The research instrument was validated by experts in the field who are also research advisers in the College of Education and Graduate School. As to content validation of the research instrument, the list of fringe benefits was lifted from the University Manual. To establish the relationship of job satisfaction with job performance, commitment and professionalism, the researchers requested copies of 2019 IPCR ratings of teachers and reports on tardiness and under time of the teachers from the Office of the Dean of the College of Education.

\subsection{Ethics in Research}

Due permission from the teachers were solicited as records on IPCR ratings and reports on teachers' tardiness for the Fiscal Year 2019 from the Dean's Office were utilized in this study.

\subsection{Methods of Analysis}

Frequency count and percentage were used to describe weighted mean was used. In terms of job satisfaction, the computed weighted means were given due verbal interpretations as follows:

\begin{tabular}{ccc}
\hline Weight & Computed Weighted Mean & Verbal Interpretation \\
\hline 5 & $4.20-5.00$ & Highly satisfied \\
4 & $3.40-4.19$ & Very satisfied \\
3 & $2.60-3.39$ & Satisfied \\
2 & $1.80-2.59$ & Slightly satisfied \\
1 & $1.0-1.79$ & Not satisfied \\
\hline
\end{tabular}

To establish the degree of relationship between job satisfaction and work performance, commitment and professionalism, test of significant correlation was used.

\section{Results and Discussions}

\subsection{Extrinsic and Intrinsic Job Satisfaction of the Teachers}

Table 2 shows the job satisfaction level of the teachers.

Accordingly, the teachers were generally "very satisfied" with their job such that, the extrinsic factors composed of salary and promotion, fringe benefits, job security and tenure, and work environment garnered an average weighted mean 
Table 2. Job satisfaction level of teachers.

\begin{tabular}{lccc}
\hline & $\begin{array}{c}\text { Weighted } \\
\text { Mean }\end{array}$ & $\begin{array}{c}\text { Verbal } \\
\text { interpretation }\end{array}$ & $\begin{array}{c}\text { Average } \\
\text { Weighted } \\
\text { Mean }\end{array}$ \\
\hline $\begin{array}{l}\text { 1. Extrinsic } \\
\text { a. Salary and promotion }\end{array}$ & 3.92 & Very satisfied & \\
$\begin{array}{l}\text { b. Fringe benefits } \\
\text { c. Job security and Tenure }\end{array}$ & 4.92 & Very satisfied & 3.89 \\
$\begin{array}{l}\text { d. Work environment and security } \\
\text { 2. Intrinsic }\end{array}$ & 3.64 & Very satisfied & (Very satisfied) \\
a. Peer and administrative working relationship & 4.19 & Very satisfied & \\
b. Material and non-material incentives & 3.69 & Very satisfied & (Very satisfied) \\
C. Material and moral support from the administration & 3.88 & Very satisfied & \\
\hline
\end{tabular}

of 3.89 (very satisfied). On intrinsic factors, which refer to peer and administrative working relationship, material and non-material incentives and material and moral support from the administration, the general rating was 3.92 (very satisfied).

\subsection{Ratings of Teacher's Performance, Commitment, and Professionalism}

The teachers' performance, commitment and professionalism for F.Y. 2019 was described by their Individual Performance Commitment Ratings (IPCR), tardiness, during the first and second half of the Fiscal Year, awards received, and years in service

During the first semester, only one out of 42 teachers was able to achieve an outstanding rating (4.77). The remaining 41 obtained very satisfactory ratings ranging from 3.76 to 4.52 . During the second semester, all of the teachers obtained very satisfactory ratings ranging from 3.97 to 4.74 .

Individual Performance Commitment Report is a bi-annual requirement to quantify the accomplishments of the teachers defining their work performance. This IPCR is mandatorily prepared by the teachers, assessed by the Program Chairperson, verified by the College Dean and approved by the University President.

As revealed by the data, all the teachers have "very satisfactory" work performance during the two semesters when they were rated. That is, the mean IPCR of the teacher for the second semester of 4.29 is 0.03 higher than that of the first semester, which is 4.26 . This means that the teachers worked very satisfactorily as they performed their work in the University.

The incurred number of times when COED teachers committed either tardiness or undertime were presented in Figure 2.

These data were a summary from the evaluation made by the Human Resource Management Office of the University on the submitted Daily Time Records (DTR) 


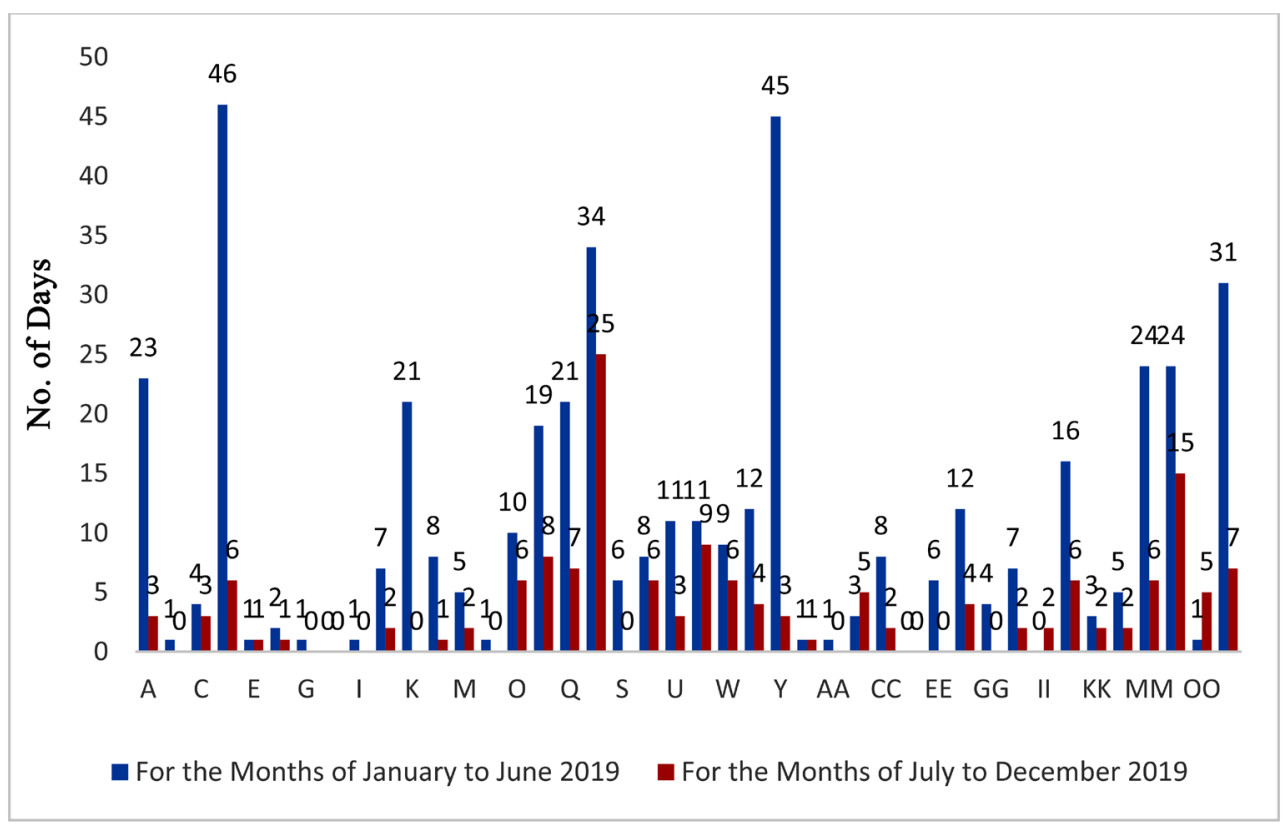

Figure 2. Reports on the Number of Times the Teachers Committed Tardiness and Under Time FY 2019.

of the teachers for the Fiscal Year 2019. Since the University required all personnel to use biometrics for work attendance, every minute late or undertime was recorded.

Based from the data shown above, the records of committed undertime or tardiness for the months of January to June for every teacher were accumulated for 6 months. If to apply Section 8, Rule XVIII of the Omnibus Rules Implementing Title, I, Subtitle A, Book V of the Administrative Code of 1987, as amended, which provides that: "SEC. 8. Officers and employees who have incurred tardiness and undertime, regardless of the number of minutes per day, ten (10) times a month for at least two (2) consecutive months during the year or at least two (2) months in a semester shall be subject to disciplinary action." None of the teachers was subjected to any disciplinary action as the records of tardiness and undertime did not meet even a portion of the required occurrence of tardiness and undertime according to Omnibus Rules. Moreover, if the data are to be scanned, there were teachers who have not committed even a single under time or tardiness, and many committed less than 10 times in 6 months. Interview with these teachers revealed that most of the time, the most common reason of tardiness was traffic and undertime, the prevailing reason was family matter.

Data show that the teachers practice professionalism in complying with the requirements of the law.

Table 3 shows the length of service of the forty-two faculty members of the College of Education. More than half of the teaching force have served the University for more than a decade already and many were recipients of Service Awards given by the Civil Service Commission and NEUST for employees who 
Table 3. Length of service in the institution and number of civil service awards received.

\begin{tabular}{|c|c|c|}
\hline Teachers & Years in Service & Number of Civil Service Awards Received \\
\hline A & 15 & 2 \\
\hline $\mathrm{B}$ & 2 & 0 \\
\hline $\mathrm{C}$ & 20 & 3 \\
\hline $\mathrm{D}$ & 9 & 0 \\
\hline $\mathrm{E}$ & 3 & 0 \\
\hline $\mathrm{F}$ & 3 & 0 \\
\hline G & 40 & 7 \\
\hline $\mathrm{H}$ & 20 & 3 \\
\hline I & 26 & 3 \\
\hline $\mathrm{J}$ & 3 & 0 \\
\hline $\mathrm{K}$ & 9 & 0 \\
\hline $\mathrm{L}$ & 12 & 1 \\
\hline M & 3 & 0 \\
\hline $\mathrm{N}$ & 32 & 5 \\
\hline $\mathrm{O}$ & 6 & 0 \\
\hline $\mathrm{P}$ & 29 & 4 \\
\hline $\mathrm{Q}$ & 25 & 4 \\
\hline $\mathrm{R}$ & 15 & 2 \\
\hline S & 9 & 0 \\
\hline $\mathrm{T}$ & 7 & 0 \\
\hline $\mathrm{U}$ & 12 & 1 \\
\hline $\mathrm{V}$ & 3 & 0 \\
\hline $\mathrm{W}$ & 3 & 0 \\
\hline $\mathrm{X}$ & 13 & 2 \\
\hline $\mathrm{Y}$ & 15 & 2 \\
\hline $\mathrm{Z}$ & 2 & 0 \\
\hline $\mathrm{AA}$ & 9 & 0 \\
\hline $\mathrm{BB}$ & 15 & 2 \\
\hline CC & 5 & 0 \\
\hline $\mathrm{DD}$ & 21 & 3 \\
\hline $\mathrm{EE}$ & 7 & 0 \\
\hline $\mathrm{FF}$ & 3 & 0 \\
\hline GG & 21 & 3 \\
\hline $\mathrm{HH}$ & 2 & 0 \\
\hline II & 15 & 2 \\
\hline $\mathrm{JJ}$ & 11 & 1 \\
\hline
\end{tabular}




\section{Continued}

\begin{tabular}{lll}
\hline KK & 26 & 3 \\
LL & 9 & 0 \\
MM & 7 & 0 \\
NN & 5 & 0 \\
OO & 4 & 0 \\
PP & 25 & 4 \\
\hline
\end{tabular}

Table 4. Relationship between job satisfaction and teachers' job performance, professionalism and commitment.

\begin{tabular}{ccc}
\hline Variable & Computed $\mathbf{r}$ & P-value \\
\hline Years in sevice & 0.0770 & $0.076^{*}$ \\
Awards & 0.0768 & $0.0756^{*}$ \\
Tardiness & 0.0050 & $0.6610^{*}$ \\
IPCR & 0.0001 & $0.9395^{*}$ \\
\hline
\end{tabular}

*Not significant at $\mathrm{p}=0.05$.

have served 10 years, 15 years, 20 years, 25 , years, 30,35 and 40 years. These awards are testaments of the teacher's commitment to their chosen profession and vocation.

\subsection{Test of Significant Relationship between Job Satisfaction and Teachers' Job Performance, Professionalism, and Commitment}

Table 4 shows the significant relationship between job satisfaction and teachers' Job performance, professionalism and commitment.

The computed $\mathrm{p}$-values of $0.076,0.0756,0.6610$, and 0.9395 for years in service, awards, tardiness, and IPCR rating, respectively are all greater than 0.05 . Hence, there is enough statistical evidence to accept the null hypothesis and conclude that there is no significant relationship between job satisfaction and teachers' job performance, professionalism and commitment at $5 \%$ level of significance.

The results of the study are in contrast with the findings of Bahani (2013) [6] and Cambe (2018) [7] whose findings established that there is a significant positive relationship between the workers' job satisfaction and performance.

Several studies have been conducted which demonstrated the relationship between job satisfaction and organizational commitment. In a study carried out by Aydogdu and Asikgil (2011) [8] found that a significant relationship between job satisfaction and affective commitment of the employees working in the service and production industry. Results also showed that there is a significant relationship between job satisfaction and normative commitment. Furthermore, they also found a significant and positive relationship between job satisfaction and continuance commitment. In contrast, hence, supporting the findings of the 
present study, the study conducted by Ahmad and Oranya (2010) [9] showed that there is no significant correlation between job satisfaction and continuance commitment.

On the other hand, the finding as to no significant relationship between the job satisfaction and length of service is supported by the findings of the study of Oshagbemi (2000) [10]. The latter showed that overall job satisfaction of university teachers is not significantly correlated with length of service in higher education.

\section{Conclusion}

The teaching force of the College was very satisfied of their job, with very satisfactory job performance, not a single one was a violator of Omnibus Rules on tardiness and undertime, and highly committed to have stayed in the profession for decades and being consistent in receiving Civil Service Awards. Job satisfaction was found of no significant relationship with work performance, professionalism and work commitment.

\section{Recommendations}

Based from the conclusions above, it is suggested that results of this study be forwarded to the University Officials, Faculty and Staff Union Officers, and to the teachers, for acknowledgement and to serve as basis for any policy revision or formulation related to faculty development. The same study be conducted, at least, every two years, for the updating of records and work environment condition of the teachers. To elevate the "very satisfied" rating to "highly satisfied" on job satisfaction, it is recommended to revisit the policies on the availment of fringe benefits, especially, on scholarship, study leave, and sabbatical leave.

\section{Conflicts of Interest}

The authors declare no conflicts of interest regarding the publication of this paper.

\section{References}

[1] Smith, P.C. (2008) The Measurement of Satisfaction in Work and Retirement. Rand McNally and Company, Chicago.

[2] Syptak, J.M., Marsland, D.W. and Ulmer, D. (1999) Job Satisfaction: Putting Theory into Practice. Family Practice Management, 6, 26-30. http://www.aafp.org/fpm/991000fm/26.html

[3] Judge, T.A. and Church, A.H. (2003) Job Satisfaction: Research and Practice. Industrial and Organizational Psychology: Linking Theory with Practice. Oxford, UK: Blackwell, 166-198.

[4] Bernstein, D.A. and Nash, P.W. (2008) Essentials of Psychology. 4th Edition, Cengage Learning, Boston.

[5] Judge, T.A., Bono, J.E., Thoresen, C.J. and Patton, G.K. (2001) The Job Satisfaction-Job Performance Relationship: A Qualitative and Quantitative Review. Psy- 
chological Bulletin, 127, pages 376-407.

https://doi.org/10.1037/0033-2909.127.3.376

[6] Bahani, S.A. (2013) The Relationship between Job Satisfaction and Job Performance: A Case Study of a Malaysian Electronic Organization.

[7] Cambe, E. (2018) Relationship among Job Satisfaction, Work Performance, and Profile of Olivarez College Employees: Inputs to a New Human Resource Development Program.

[8] Aydogdu, S. and Asikgil, B. (2011) An Empirical Study of the Relationship among Job Satisfaction, Organizational Commitment and Turnover Intention. International Review of Management and Marketing, 1, 43.

[9] Ahmad, N. and Oranye, N.O. (2010) Empowerment, Job Satisfaction and Organizational Commitment: A Comparative Analysis of Nurses Working in Malaysia and England. Journal of Nursing Management, 18, 582-591.

https://doi.org/10.1111/j.1365-2834.2010.01093.x

[10] Oshagbemi, T. (2000) Is Length of Service Related to the Level of Job Satisfaction? International Journal of Social Economics, ISSN: 0306-8293 